\title{
THE PREFACE AS STAGE: THE THEATRICAL TROPE AND THE PERFORMANCE OF AUTHORIAL IDENTITIES IN THE NINETEENTH CENTURY
}

\author{
Geraldo Magela Cáffaro* \\ Universidade Estadual de Montes Claros \\ Montes Claros, MG, BR
}

\begin{abstract}
This essay explores references to the theatre in prefaces by Charles Dickens, Nathaniel Hawthorne, and Henry James. Particular emphasis is given to the way these authors employ figures such as stage manager and dramatist to reach their audiences and project authorial images. The figures in question are historicized and discussed in light of the concepts identified by the terms performative and theatre of images and the argument proposed is that references to the theatre reveal tensions between self-display and self-concealment, as well as between the assertion of authority and its subversion and fragmentation in nineteenth-century prefatory writing.
\end{abstract}

Keywords: Preface; Theatre; Authorship; Performance; Nineteenth Century

Critics and authors in general have often resorted to spatial metaphors such as threshold, doorstep, and vestibule to refer to prefaces and other introductory matter. While these metaphors illuminate the role prefaces have traditionally played in offering a transition to the books they antecede, an analysis of other spatial metaphors may show how these texts also served as loci of enunciation and platforms for self-fashioning and the performance of authorship. This is the case of the theatrical trope used by authors in the nineteenth century. This trope foregrounds the performative aspect of authorship and bears witness to the authors' painstaking search for legitimacy and authority. By examining examples from Charles Dickens, Nathaniel Hawthorne, and Henry James, I shall argue that references to the theater in these authors' prefatory writing reveal tensions between self-display and self-concealment, as well as between authorial selffashioning and the fragmentation of the author into different selves.

The authority of the theater in the nineteenth century stemmed from its being a much older genre than the novel and a more popular form of entertainment. Although the genre is the underlying instance of authority in most cases, this authority is best perceived in a host of figures and theatrical elements evoked by preface writers. The two main figures I shall be concerned with in my readings are the stage manager and the dramatist. I shall also give particular attention to the stage, the controlling metaphor of this essay and one of the loci of enunciation for preface speakers to perform authorial roles. The idea of authorship as performance has been frequently used in analyses of the authors under consideration. In my readings of the prefaces I draw from studies such as Mario Ortiz-Robles's (2011); Joseph Litvak's (1992); and Eve Kosofsky Sedgwick's (2003). In addition to helping in the analysis of authors such as Dickens and James, Litvak and Sedgwick offer, respectively, the historical and theoretical bases for my discussion of the theatrical trope in the prefaces. The two main concepts I shall be working with are the performative and the theatre of images, the latter of which I draw from Reinaldo Marques (2012). 
In Caught in the Act: Theatricality in the Nineteenthcentury English Novel (1992), Joseph Litvak contends that nineteenth-century novels by Jane Austen, Charles Dickens, and Henry James destabilize the "distinction between a society of spectacle and a society of surveillance" (ix). The nineteenth century, according to Litvak, was marked by a "fall from the theatricality of eighteenth-century culture into the world of domesticity, subjectivity, and psychology, whose intimate, personalized scale, far from providing refuge from surveillance, installs it..." (ix). But as he goes on to add, the nineteenth-century texts he examines are theatrical (albeit less overtly than in the eighteenth century) because they are caught in the Foucaultian web of "vigilance and visibility - of looking and being looked at" (x). Notwithstanding the fact that Litvak deals mostly with novels, I see prefatory writing in the period as a product of the same "fall from theatricality" and the privatization of culture. Moreover, the pattern "vigilance/visibility" is largely applicable to the general use of the preface as a means of audience control, selfpromotion, and performance.

My immediate source for using terms such as performance, performativity, or, more aptly, performative, is Eve Kosofsky Sedgwick's Touching Feeling: Affect, Pedagogy and Performativity (2003). As the author puts it, "Performative' at the present moment carries the authority of two quite different discourses, that of theater on the one hand, and of speech act theory and deconstruction on the other" (7). Still according to Sedgwick, whereas the theater is associated with the extroversion of the actor's performance, the speech act testifies to an introspective movement of the speaker (7). This is because in J.L. Austin's theory of speech acts, performative is characterized as being an utterance always in the first-person, singular, present, indicative. In Austin's taxonomy, performative is distinguished from constative, a type of utterance whose function is to describe events. By contrast, performative is linked with the act which the verb is meant to perform in real situations of communication; that is, "I promise" promises, "I apologize” apologizes, "I declare” declares.

Where Austin sees a linkage between signifier (the performative verb) and the act, the deconstructive take on "performativity," especially in Paul de Man and J. Hillis Miller, finds a "dislinkage precisely of cause and effect between the signifier and the world" (Sedgwick 7). There is also in de Man, as Sedgwick notes, the possibility of seeing the relationship between the performative and its reference as one of "torsion" and "mutual perversion" (7). Given the odd nature of the prefaces being examined, turned both to the reader and to the "inmost me" of the speaker, all of the above perspectives are pertinent to the analyses. In this light, the "mutual perversion" of performativity and reference is especially productive when it comes to looking at the images convoked by the authors in their texts.

Reinaldo Marques indicates an alternative way in which to understand the "mutual perversion" of performativity and reference when he writes about the roles played by authors in modernity. Instead of focusing on single acts or utterances, he treats the author within the scope of a multiplicity of figurations disseminated through media technologies. As he explains: "the writer is broken into several figurations: ... fragments of life disseminated in interviews, narratives, chats and reports" (61). The author disseminated in this way is, as are all of us, part of a "theatre of images," an array of scenic identities mediated by countless supports such as "photos, blogs, twitter, facebook, orkut, youtube, podcasts" (sic 60). As Marques goes on to note: "Dissociated from the empirical personage, the author constitutes itself as a discursive strategy, thus signaling the existence of discontinuities between discourse and the real, which problematizes the play of identities and symmetries" (65). Also persuasive in Marques's text is the argument according to which the condition of "subject-image" is what guarantees the afterlife of authors. Although the authors I discuss had access to fewer media for disseminating their images, they were aware of the need to become icons to survive. Dickens's, Hawthorne's, and James's world was already a world of words, images, performance, and wide circulation. Their prefaces, in particular, evidence the need to constitute "theaters" and to perform roles in accordance with their ambitions, times, and an ever expanding literary market. 
The "theater of images" adds a different level of interpretation to "the performative." Not restricted to speech acts or to theatrical performance, it can refer to a whole range of activities, behavioral patterns and interventions. In this sense, it can be read along Stephen Greenblatt's self-fashioning, which "invariably crosses the boundaries between the creation of literary characters, the shaping of one's own identity, the experience of being molded by forces outside one's control, the attempt to fashion other selves" (3). Thus, authorial performance, one of the means by which selffashioning processes are made public, is seen as a result of both intentional impulses and unconscious forces. Authors fashion themselves in and through their choices of images, representational spaces, tones, narratives, but they are also fashioned by history, location, and by the systems of signs and cultural references they share with society as a whole.

\section{Dickens and Hawthorne as Stage-managers}

"Before the Curtain," William Makepeace Thackeray's introduction to Vanity Fair (1848), is a plausible point of departure for a discussion on the theatrical trope in nineteenth-century prefatory writing. This iconic text was published at the end of the novel's serial run in 1848 and called attention for its confluence of author and "manager of the Performance." This theatrical persona mediates between the world of the "fair" - which extends to that of the readers - and the puppet show standing for the novel. As an outside observer, he sees the fair with condescension and "melancholy," and after introducing the audience to the contents of the story, he thanks them for welcoming his "show," bows to "his patrons," and "retires" before the curtain rises (5). As Joan Stevens explains with regard to the theatrical analogy and the serialization of Vanity Fair: "The novel, like an established play, has been making regular appearances; its author may well have a sense that the characters are an acting company and he their stage manager" (291). Despite the popularity of Vanity Fair and its introduction, Thackeray was not the first Victorian writer to use the theatrical analogy. As Stevens observes, Dickens had used the image of the stage manager ten years before: first in an "Address to Readers" appended to series Number 10 (January, 1837) of the Pickwick Papers; and later in his "Editor's Address on the completion of the First Volume" of Bentley's Miscellany (June, 1837). It is worth adding that, although the stage manager is absent from the 1847 preface to the Cheap Edition of Pickwick Papers, the theatrical analogy is also present there. In what follows I shall deal exclusively with the two authorial prefaces accompanying the novel: the Address to series Number 10 and the 1847 Preface to the bound volume, both of which are reproduced in the Clarendon Edition edited by James Kinsley.

I reserve some space here, before reading the prefaces, for a few words on the relationship of Dickens with the theatre. According to Simon Callow, Dickens's character was often regarded as theatrical by his contemporaries (xi). Before becoming a novelist, Dickens had taken part in several amateur theatricals, had written his own plays, and continued to perform later on in life with his reading tours. What is interesting to keep in mind with regard to Dickens and the theatre is the way he fashioned himself as a performer and the several roles he created for himself in his career.

The Preface to series Number 10 of the Pickwick Papers contains a formula Dickens would use in several subsequent prefaces (including the one to the first series of Sketches by Boz (1836), published a month later). This formula consisted of the use of a third person voice, a deferential tone, and the celebration of the success and popularity of the series. In the preface, Boz starts by promising not to prolong the story beyond the previous estimate of twenty numbers. He also refers back to the fictional device of the papers of the Pickwick Club - which he kept under his supervision - to maintain interest in the numbers to come. He then ends the piece with the theatrical metaphor Thackeray adopted in Vanity fair:

With this short speech, Mr. Pickwick's StageManager makes his most grateful bow, adding, on behalf of himself and publishers, what the late eminent Mr. John Richardson, of Horsemonger Lane Southwark, and the Yellow Caravan with the Brass Knocker, always said 
on behalf of himself and company, at the close of every performance -

"Ladies and gentlemen, for these marks of your favor, we beg to return you our sincere thanks; and allow us to inform you, that we shall keep perpetually going on beginning again, regularly, until the end of the fair." (882).

In this passage, the image of the stage manager is reinforced by the reference to the famous itinerant dramatic showman, John Richardson. While the allusion and the speech make the dramatic effect seem more concrete, they disrupt the unity of the authorial voice and make "Boz" appear as a ventriloquist. "Performative" here operates on two registers: that of role-playing (Boz appearing as Richardson) and of a speech act in the Austinian sense: the speaker "begs," asks for permission, and promises to offer more performances to the public. With a formulaic speech and the reference to Richardson, Boz selects a contemporary and popular form of entertainment, and thus aims to reach larger audiences.

The formality of the address ventriloquized by Boz contrasts with the liberty conveyed through the image of the "friend taken by the button" in the preface to the Cheap Edition. Dickens opens his preface with the following words: "An author who has much to communicate under this head, and expects to have it attended to, may be compared to a man who takes his friend by the button at a Theatre door, and seeks to entertain him with a personal gossip before he goes in to the play" (883). The passage is reminiscent of Samuel Taylor Coleridge's "The Rime of the Ancient Mariner" (1798), in which an old grizzled sailor approaches a young wedding-guest and starts telling his story. In both cases, the story-teller stands in the way of another performance (the play in Dickens's preface and the wedding in Coleridge's poem), thus displacing the "stage" and turning it to himself. Also noteworthy in the passage is that the stated purpose of the address is not initially to express intent, define a theory of art, offer dodges for criticism, or any of the functions listed by Gérard Genette. The author "seeks to entertain," a role associated with the fictional/theatrical universe. The theater-goer, however, stands at the door of the Theater, and he hears the story as a friend of the author's. Figuring the reader as a friend was a common tactic in Dickens's prefatorial self-fashioning. In turn, the situation sets the scene for Dickens to perform his identities through an account of origins.

In this account, he appears as a "man of three-andtwenty", twelve years before the present address. He narrates how the publishers offered him the chance to write something to be published in "shilling numbers," associated in the author's mind with the material "carried about the country by pedlars, and over some of which I remember to have shed innumerable tears, before I served my apprenticeship to Life" (884). The narrative shifts to an even earlier time when Dickens was possibly a child and a reader of the stories that made him cry. Everything is magnified and intensified: his growth is depicted as "apprenticeship to Life" and the reader sheds tears over the books he reads.

Dickens's appeal to emotions continues in the next paragraph in which he tells the story of his becoming an author with the publication of his first sketch in a magazine. The passage is introduced in a suggestively theatrical manner and the display of feelings and reactions gains prominence as the narrative unfolds:

\footnotetext{
When I opened my door in Furnival's Inn to the managing partner who represented the firm, I recognized in him the person from whose hands I had bought two or three years previously, and whom I had never seen before or since, my first copy of the Magazine in which my first effusion - dropped stealthily one evening at twilight, with fear and trembling, into a dark letter-box, in a dark office, up a dark court in Fleet Street - appeared in all the glory of print; on which occasion by the bye, - how I recollect it! - I walked down to Westminster Hall, and turned into it for half-an-hour, because my eyes were so dimmed with joy and pride, that they could not bear the street, and were not fit to be seen there. (884).
}

The dramatization of the moment is conveyed through feelings ("fear and trembling") and through the repetition of the adjective to describe the place where he had deposited his "hopes of future fame:" "dark letterbox," "dark office," "dark court." Dickens interrupts the narrative with an exclamation: "how I recollect!", 
which adds to the theatrical effect of his account. And if the mere description of emotions is not enough, he ends by rendering those feelings visible: "my eyes were so dimmed with joy." The passage additionally shows Dickens's sense of "being looked-at" - “[my eyes] were not fit to be seen there" - one of the characteristics of the Foucaultian "vigilance/visibility" pattern which Litvak articulates with nineteenth-century theatricality.

As Mario Ortiz-Robles remarks in "Dickens Performs Dickens" (2011), "the prefaces can be said to stage a curious confluence of history-ofthe-book narratives with those of the constructionof-the-subject by virtue of their performativity" (474). As he writes further on in his essay: "The fictionalization of Dickens in the prefaces thus becomes a disfiguration of Dickens the author insofar as it is a deliberate attempt to transform the author into a character, the agent into an actor" (476). I would add that this disfiguration happens by virtue of a multiplicity. The several personas, narratives, and roles enacted by the author (stage manager, reader, child, friend) are engulfed in the "theatre of images" Reinaldo Marques has described and show how Dickens's prefaces transform authorial address into an opportunity for performance.

Hawthorne also created his own "theatre of images" in the figures of guide, host, decapitated surveyor, obscure man of letters, and displaced national author. Although Hawthorne was prone to dramatize his own authorship in the prefaces just as Dickens had done in his, his tactic was based more on self-deprecation than on self-celebration. Lacking the confidence (and popularity) of Dickens to approach his readers more directly, Hawthorne opted instead to thematize the difficulty of the relationship between author and reader, a difficulty largely rooted in his resentment over not having enough readers. His use of the theatrical trope in the preface to the Marble Faun (1859), thus, is motivated less by a fit of extroversion than by his clinging to a formal and distant form of address to compensate for his failures to establish an intimate contact with the reader in the model of Dickens's stance. Still, his awareness of prefatory writing as a special instance of performance is notable in the opening lines of that preface: "It is now seven or eight years (so many, at all events, that I cannot precisely remember the epoch) since the Author of this Romance last appeared before the Public" (853). The author's "appearances" refer to Hawthorne's previous prefaces, "addressed nominally to the Public at large, but really to a character whom he felt entitled to use far greater freedom" (853). After expressing disappointment at never having "encountered" this character, he mentions that he wrote for him/her despite being completely ignored by "the great Eye of the Public." Although this great "Eye" is unequivocally linked with the reader in the text, it could also be brought to bear on the experience of a theater-goer witnessing the author's "appearances."

The impulse to go public seen in the preface to the Marble Faun is at odds with a more private tendency found in this text. The author superimposes the epistolary over the theatrical, thus creating a clash between the public and private realms and enhancing even more the resentment which is at the heart of the address as a whole:

Unquestionably, this Gentle, Kind, Benevolent,
Indulgent, and most Beloved and Honoured
Reader, did once exist for me, and (in spite of
the infinite chances against a letter's reaching
its destination, without a definite address) duly
received the scrolls which I flung upon whatever
wind was blowing, in the faith they would find
him out. But is he extant now? In these many
years, since he last heard from me, may he not
have deemed his earthly task accomplished,
and have withdrawn to the Paradise of Gentle
Readers, wherever it may be...? If I find him
at all, it will probably be under some mossy
grave-stone, inscribed with a half-obliterated
name, which I shall never recognize. (853).

The author finally accomplishes his vengeance on the reader; he has consigned him to the same place of obscurity as the one he occupies as a writer. The antagonism between author and reader suggested in the passage is tinged with jocularity, but it is still capable of maintaining the tension between both parties and of contributing to the dramatic effect of the address. 
Thomas R. Moore comments on the tensions created by Hawthorne in his prefaces in "Poses in the Prefaces: A Rhetoric of Oppositions" (1994): "Hawthorne's strategy in the prefaces - his double purpose - is first, to address both his popular audience and a more discerning readership. But second, and more important, his purpose is to employ the dialectical tension created by his rhetoric of oppositions to say what he could not say outright" (74). Moore also notes that Hawthorne used his "rhetoric of oppositions" when he was writing "outside the parameters - and masks of fiction" (74). Hawthorne's rhetoric of oppositions can alternatively be understood as pointing to a lack of definite reference in the prefatory discourse (the "mutual perversion" of performativity and reference I mentioned earlier on); in such case, Hawthorne would not be writing as if he were "outside the parameters of fiction" because the fictive - as an intentional act which selects and appropriates elements from other referential fields (Iser xiv) - is already at play both at the threshold and in the main text.

Hawthorne makes a different use of the theatrical trope in his 1852 preface to The Blithedale Romance. Still, just as the theatrical in the former preface marks a distance from his intended "real" reader, in the latter this distance is marked in relation to the historical or "real" elements serving as immediate points of comparison for the story. Naturally, Hawthorne cannot disavow the relationship completely: he based his satire of utopian socialism on his own sojourn in the Brook Farm community in 1841. The novel also features one of Hawthorne's few first-person narrators: Miles Coverdale, a bachelor poet whose misanthropic nature and self-doubt parallels Hawthorne the prefacer. In the preface to the novel, Hawthorne writes: “... his present concern with the Socialist Community is merely to establish a theatre... where the creatures of his brain may play their phantasmagorical antics, without exposing them to too close a comparison with the actual events of real lives" (247). The theatrical analogy reinforces the proximity between the author and Miles Coverdale. As Brenda Wineapple notes: "Hawthorne's first-person narrator... believes he can best hold himself together by holding himself apart and conceives the world as a theatre, the book's dominant image" (247). The immediate subtext of The Blithedale Romance is indeed Shakespeare's As you Like it; the rural community of the novel is compared to the Forest of Arden and their members with the banished Duke and his party.

The theatre aligns with the "neutral territory," another image Hawthorne uses to defend his theory of the Romance in "The Custom-House: Introductory to The Scarlet Letter" (149). In both cases, Hawthorne insists on the disconnection of fiction from reality and guides the reader towards the adoption of a "picturesque" view of the situations described. In the preface to the Blithedale Romance, he shows hints of the perception he would express more clearly in 1859 with regard to the place of The United States in affording elements conducive to producing that "picturesque" effect. The passage I quote comes immediately after the reference to the "theatre:"

In the old countries, with which Fiction has long been conversant, a certain conventional privilege seems to be awarded to the romancer; his work is not put exactly side by side with nature... Among ourselves, on the contrary, there is as yet, no Faery Land, so like the real world, that, in a suitable remoteness, none cannot well tell the difference, but with an atmosphere of strange enchantment, beheld through which the inhabitants have a propriety of their own. (633).

As in the preface to The Marble Faun, Hawthorne idealizes the "Old Countries" in which writers supposedly have more freedom to do as they please in representing reality. In what seems to be an example of bad faith, however, Hawthorne shifts the attention from the writer to the "setting" which contains in itself the qualities that place it at a remove from nature.

Hawthorne's theatre, thus, shows his attempt to control the reader, his images before the public, and the social threats he encountered in his times. But while staging authorial surveillance, he also reveals fragility in relation to the elements that imposed constraints upon his imagination, literary production, and autonomy. The "neutral territory" he finds in the stage allows him, despite that fragility, to imagine himself as merging 
with the stories he creates and transforming himself into spectacle before "the great Eye of the Public."

\section{Drama and Dramatist in Henry James's Prefaces}

The Prefaces to Henry James's New York Edition are some of the most prominent examples of authorial performance in literary history. Not only was the Edition conceived as a monumental "act" and an authorial statement, but the texts abound in analogies to the theatre. In these texts, James often appears as the "dramatist," a figure analogous, in its prefatory use, to Hawthorne's and Dickens's stage managers. But James also plays the roles of actor and spectator of his own autographical dramas as he tells them in the Prefaces. James's stage is as ambiguous in its seeming extroversion as Hawthorne's, and the uses which it serves are related not only to his affective involvement with the composition of the works but also to his theory of the novel.

The epithet "dramatist" is one of the most pervasive substitutes for "author" in the New York Edition prefaces. Its frequency is perhaps only comparable to "painter" and "adventurer," and it needs to be understood in relation to James's sustained obsession with the theater. As Leon Edel notes in Henry James: A Life (1985), much of James's autobiography A Small Boy and Others is dedicated to "detailed recounting of nights at the play - pantomimes viewed in early childhood, old theatrical billboards with their lurid synopses of the plays and picturesque names of the stage folk, excursions to the theaters of New York and later of London and Paris" (31). Among the many performances he saw were "hastily cobbled up versions of Dickens's novels, the very names of whose characters - the Scrooges and Pickwicks, Oliver Twists and Paul Dombeys -assured full house" (31). But by the time James wrote the prefaces to the New York Edition, the theater had come to be associated with failure as well, as his play Guy Domville "was howled off the stage" at its premiere in 1895 (Sedgwick 38). The Tragic Muse and The Awkward Age (volumes V and VI in the New York Edition) bear witness to the strong influence of the theater in James's novelistic production in the last decades of the nineteenth century. In their respective Prefaces, the theatrical analogy acquires special significance and illuminates aspects of James's authorial self-fashioning.

One of James's purposes in the Preface to The Awkward Age is to respond to criticism for his overuse of dialogue in the story of a young girl coming of age in fin de siècle English society. After acknowledging his emulation of the style of the French writer "Gyp," an emulation he did his best to dissimulate, he reproduces his publisher's grim verdict with regard to the novel's reception - "I'm sorry to say the book has done nothing to speak of" (108). Next, he sets about to giving himself the "reward" denied him, a reward rooted in "the singular interest attaching to the very intimacies of the effort" (109). What follows is a translation of this effort into the vocabulary of architecture. In contrast with the Preface to the Portrait of a Lady, the evoked space is not the space of domesticity, but rather something more akin to a ballroom or a stage, as the following passage shows: “....amusement deeply abides, I think in any artistic attempt the basis and groundwork of which are conscious of a particular firmness. On that hard fine floor the element of execution feels it may more or less confidently dance..." (sic 109). A couple of lines later, he writes:

I was thus to have here an envious glimpse, in carrying my design through, of that artistic rage and that artistic felicity which I have ever supposed to be intensest and highest, the confidence of the dramatist strong in the sense of his postulate. The dramatist has very to build, is committed to architecture, to construction at any cost.... This makes the active value of his basis immense, enabling him... to advance undistractedly, even if not at all carelessly, into the comparative fairy-land of the mere minor anxiety.... I rejoiced by that same token, to feel my scheme hold, and even a little ruefully watched it give me much more than I had ventured to hope. (110)

In this passage, the role of "dramatist" conflates with those of actor and spectator (let alone architect). The speaker "builds," moves in his projected stage, and "watches" his performance in retrospect. Assuming 
several roles helps James convey the sense of control he has over the many phases of the composition process. The reader is supposed to "watch" this exhibition of control and recognize the author's effort and engagement with his métier. At the same time, he/she may have a more vivid perception of this effort through the figurative rendering of this engagement. As John H. Pearson argues: "James fashions himself just as he has created characters in the novels and the tales by forming a central consciousness upon which the world is reflected and then revealed to the reader" (43). By extension, the passage shows that the world that gets reflected is also the writer's "consciousness," that is, central consciousness and world converge in the Prefaces.

James stretches the limits of the theatrical metaphor as he shifts the focus from "the dramatist" to his fictional creation. His object in The Awkward Age was to be thought of as illuminated by "lamps," each of which "would be the light of a single 'social occasion' in the history and intercourse of the characters concerned, and would bring out to the full the latent colour of the scene in question and cause it to illustrate, to the last drop, its bearing on my theme" (110). Each of these lamps would correspond to an "Act" in the play, that is, a separate section in the novel. This method would, eventually, allow the story to tell itself without any interference from the author or "dramatist." In other words, once the curtain rises, the author is nowhere to be seen, even though he has already performed his own act before the audience.

A similar idea is expressed in the Preface to The Tragic Muse. According to James, the "triumph" of the artist - otherwise called the "charm-compeller" - is to be strictly attached to the work he performs or creates (96). This position raises doubts about the status of the prefaces and the authorial statements they mediate. If the "triumph" of the artist were evident in the work, the author wouldn't need to strive so hard to justify it in these texts. This is complicated by the fact that James suggests, right at the outset, in the Preface to Roderick Hudson, that "the private history of any sincere work... looms with its own completeness in the rich, ambiguous aesthetic air" (4). Thus, the effort he makes in drawing attention to his authorial presence in the prefaces is at odds with the image of detached master he projects.

We may find a better articulation of this contradiction in the preface to The Golden Bowl. James explains that the "central consciousness" is actually a "deputy" for the "creative power otherwise so veiled and disembodied" (327). The use of this deputy, someone in the story who can give the reader a more direct access to the events described, was one of the touchstones of the type of criticism practiced by new critics following in the footsteps of James, such as Richard P. Blackmur and Percy Lubbock. The concept of central consciousness was a clever intervention in the literary field of the time and served James in his effort to superimpose literary modernity over the Realist novel of the previous generation. What the Preface to the Golden Bowl reveals, however, is that James maintains the belief in "the majesty of authorship" despite seeming to go against it: "It's not that the muffled majesty of authorship doesn't here ostensibly reign; but I catch myself again shaking it off and disavowing the pretence of it" (sic 328).

The principle of dissimulation, evident in the Preface to the Golden Bowl, is repeatedly exposed in other prefaces. I quote another passage from the preface to The Tragic Muse:

If the art of the drama, as a great French master of it has said, is above all the art of preparations, that is true only to a less extent of the art of the novel, and true exactly in the degree in which the art of the particular novel comes near that of the drama. The first half of a fiction insists ever on figuring to me as the stage or theatre for the second half, and I have in general given so much space to making the theatre propitious that my halves have too often proved strangely unequal. Thereby has arisen with grim regularity the question of artfully, of consummately masking the fault and conferring on the false quantity the brave appearance of the true. (86).

Here James accounts for the lack of balance in his tripartite division in The Tragic Muse, a division based on three different cases or characters in the story (Miriam Rooth, Nick Dormer, and Peter Sherringham). The theatrical metaphor in this context takes on a 
different function from the other situations examined so far. Still, the rationale behind the conception of the first half of the novel resembles that of "building," which I examined in the Preface to The Awkward Age. The result is that the building, by contrast with the latter preface, threatens to weigh down on the body of the work as a whole. The author comes to rescue the safety and harmony of the architecture, but this rescue is performed after the construction.

James might have failed to achieve the organic unity so crucial to his reputation as a novelist, but in the Tragic Muse he delivers one of his most successful heroines, Miriam Rooth, who also serves as a point of comparison with the author. It must be noted that the "triumph" of the artist I have discussed above is a reference to both the actress and to the dramatist. Additionally, Miriam Rooth exerts strict control over her public image while forging "private" identities to satisfy her audiences, an attitude that antedates the practice of contemporary celebrities and that parallels James's careful manipulation and selection of his personal experiences in the prefaces. Thus, the senses in which James's prefaces engage performativity are various: firstly, they create spaces in which both authorial and actorial performance can be thematized and enacted; secondly, they dislocate the empirical author and foreground the disconnection of reference and discourse; thirdly, they evoke the authority of the theater and "invent" literary modernity; and lastly, they participate in the phenomenon of the promotion of private life, a phenomenon intimately related to Reinaldo Marques's "theatre of images." Still, one last aspect of James's performativity has not been fully articulated here: the ways in which the author relies on affect in his accounts of the processes of creation.

Affect is as important an aspect of James's prefatory discourse as it is of Dickens's and Hawthorne's, and in the three authors' texts one gets a sense of the relationship between different modes of affect (pride, resentment, pleasure) and the theatrical. But the expression of affect takes on unprecedented variety and intensity in James's collection of prefaces. Notably, the author often finds solace for his failures in the recollection of the "excitement" the adventure of composition afforded him. The act of revising the old works also triggers a series of reactions which the author displays in graphic and erotic terms. Eve Kosofsky Sedgwick brilliantly traces some of the erotic undercurrents in James's New York Edition. In her chapter "Shame, theatricality, and queer performativity: Henry James's The Art of the Novel" (from the aforementioned Touching Feeling) these erotic undercurrents get mapped around a number of lexical occurrences of sexual resonance, such as "fond," "issue," "center," "glove," among others. The critic's argument is that "tuning in" to these lexica, which are closely related to James's intimate involvement with his younger selves, his works, and with the act of "reparenting" them in The New York Edition, gives readers access to James's eroticism "not as superior, privileged eavesdroppers on a sexual narrative hidden from himself; rather, it is an audience offered the privilege of sharing in his exhibitionistic enjoyment and performance of a sexuality organized around shame" (54). The shame Sedgwick identifies in James's rendering of his early stories as immature or monstrous is, thus, one of the means of self-display in his prefaces.

Although James's "theatre" is more multivalent and less formulaic than Dickens's and Hawthorne's, it is also dependent on affect, play, audience, and a tradition. Underlying the theatrical analogy in the texts examined above is the belief in authorship as a "drama" to be performed before the reader. In the nineteenth century, this drama served to coordinate positions, establish authority, and disseminate "images" of the author in a context marked by a growing number of readers and the proliferation of media and technologies. Asserting one's authority in the literary field involved, paradoxically, denying that authority at some moments, which is in consonance with the tension I referred to at the beginning of this article. Tension, as we have seen in the analyses, is expressed through oppositions, antagonism, contradictions, conflicting roles and specific modes of affect. Clearly, the multiplicity of images the author sends out is at odds with the way they are often canonized; instead of coherent unities, what we have are discontinuities and shifting identities. But the prefaces studied do more than simply show patterns of dissimulation, theatricality, and manipulation; they 
are also registers of historically specific systems of belief and of personal, individual experiences which, as Greenblatt has astutely formulated, often blur distinctions between life and performance (3).

\section{Notes}

1. See Gérard Genette's Paratexts: Thresholds of Interpretation (2).

2. My translation. "O escritor se decompõe em diversas figurações: ... fragmentos de vida disseminados em entrevistas, depoimentos, bate-papos, reportagens."

3. My translation. "fotos, blogs, twitter, facebok, orkut, youtube, podcasts."

4. My Translation. "Dissociado do personagem empírico, o autor se constitui então como estratégia discursiva, indiciando a existência de descontinuidades entre o discurso e o real, que problematizam o jogo das identidades e simetrias."

5. See Chapter 9, "The Functions of the Original Preface," in Paratexts: Thresholds of Interpretation (196-237).

6. All citations are to the Collected Novels of Hawthorne's works published by the Library of America.

7. Henry James's autographic Prefaces to the New York Edition were posthumously collected in a single volume by Richard P. Blackmur, entitled The Art of the Novel (1834). All citations are from the 1837 edition of the collection.

\section{References}

Callow, Simon. Charles Dickens and the Great Theatre of the World. New York: Vintage Books, 2012. Print.

Dickens, Charles. The Pickwick Papers. Ed. James Kisnley. Oxford: Clarendon P, 1986. Print.

Edel, Leon. Henry James: A Life. New York: Harper \& Row, 1985. Print.

Genette, Gérard. Paratexts: Thresholds of Interpretation. Trans. Jane E. Lewin. Cambridge: Cambridge University Press, 1997. Print.

Greenblatt, Stephen. Renaissance Self-fashioning: From More to Shakespeare. Chicago: U of Chicago Press, 1980. Print.

Hawthorne, Nathaniel. Collected Novels. New York: The Library of America, 1983. Print.

Iser, Wolfgang. The Fictive and the Imaginary: Charting Literary Anthropology. Baltimore: John Hopkins University Press, 1993.Print.
James, Henry. The Art of the Novel. New York; London: C. Scribner's Sons, 1937. Print.

Litvak, Joseph. Caught in the Act: Theatricality in the Nineteenth-century English Novel. Berkeley: University of California Press, 1992. Print.

Marques, Reinaldo Martiniano. "O Arquivo Literário e as Imagens do escritor." Orgs. Eneida M. de Souza, Eliana da Conceição Tolentino, Anderson Bastos Martins. $O$ Futuro do Presente: Arquivo, Gênero, Discurso. Belo Horizonte: Editora UFMG, 2012. 59-89. Print.

Moore, Thomas. R. "Poses in the Prefaces: A Rhetoric of Oppositions." A Thick and Darksome Veil: The Rhetoric of Hawthorne's Sketches, Prefaces, and Essays. Boston: Northeastern University Press, 1994. 73-99. Print.

Ortiz-Robles, Mario. "Dickens performs Dickens." ELH 78.2 (2011): 457-78. Print.

Pearson, John H. The Prefaces of Henry James: Framing the Modern Reader. University Park: Pennsylvania State UP, 1997. Print.

Sedgwick, Eve Kosofsky. Touching Feeling: Affect, Pedagogy, Performativity. Durham: Duke University Press, 2003. Print.

Stevens, Joan. "A Note on Thackeray's 'Manager of the Performance." Nineteenth-Century Fiction 22.4 (1968): 391-97. Print.

Thackeray, William Makepeace. "Before the Curtain." Vanity Fair: A Novel without a Hero. London: Penguin, 2002. 5-7. Print.

Wineapple, Brenda. Hawthorne: A Life. Alfred A. Knopf: New York, 2003. Print.

Recebido em: 12/07/2016 Aceito em: 24/08/2016 